\title{
Transparency of Taxpayers' Rights and Obligations
}

\author{
Ramadan Kryeziu \\ Ph.D. Candidate, “J.J. Strossmayer" University of Osijek, \\ Faculty of Economics, Osijek \\ Bahtijar Berisha \\ Ph.D. Candidate, “J.J. Strossmayer" University of Osijek, \\ Faculty of Economics, Osijek \\ Sakip Imeri \\ Ph.D. Candidate, "J.J. Strossmayer" University of Osijek, \\ Faculty of Economics, Osijek \\ Mustafe Hasani \\ Ph.D. Candidate, "J.J. Strossmayer" University of Osijek, \\ Faculty of Economics, Osijek
}

Doi: $10.2478 / \mathrm{mjss}-2018-0070$

\section{Abstract}

Since the goal of tax system is based on self-declaration and voluntary compliance, with this study we intend to know on 'Taxpayers' Perceptions with regard of Tax Administration of Kosovo. We believe that most effective way to keep and enhance the voluntary compliance is through mutual trust and respect between TAK and Kosovo taxpayers." This is the reason for the study and making recommendations on findings with a special emphasis on improvements of TAK services for the public, in order to fulfill expectations and to provide taxpayers with services they deserve. This work aims to identify the weaknesses and short-falls. Based on findings of this work through the survey with Kosovo taxpayers, we will recommend our ideas in order for the taxpayers to enjoy their legal rights and we will not allow for these rights to be violated in any form.

Keywords: Tax Administration of Kosovo, voluntary Compliance, self-declaring.

\section{Introduction}

Kosovo economy suffers a large tax gap, which is mainly a consequence of informal economy and the tax avoidance by some businesses and individuals, which act in disproportion with rules1. Failure to comply with tax obligations by taxpayers causes huge problems with tax revenues. TAK offices in Kosovo are more and more focused on development of sustainable and effective strategy to resolve these outstanding issues of Kosovo tax policy2. However, one of the factors that hamper this process is the lack of reliable and reflective data on this issue. Kosovo lacks the study on taxpayers that would accurately measures the perceptions and opinions of individuals and business in Kosovo on related tax issues. Results coming out from this study aim to help on drafting the effective and constructive strategy with priorities on areas of high importance based on taxpayers of Kosovo.

The support on project for TAK is mainly directed towards the improvement of tax inspectors' capacities, increase of effectiveness and legal impartiality of audits, and strengthening of 
communication channels between Kosovo taxpayers and TAK offices and officials.

This report analyzes and synthesizes findings of a number of activities on data collection, respectively quantity survey, half-structured interviews and focus groups.

First, this report intends to inform contractor by finding the pattern of quantity findings of study in five main areas: Transparency of Taxpayers' Rights and Obligations; Compliance Cost; Correct Professionalism and Treatment by TAK; Orientation towards Service; and in the end, Motivation for Compliance.

This report provides the context of policy and tax system of TAK in Kosovo, through the follow-up of data, strategies, direction and new goals and initiations. Tax context of Kosovo is filled out with a brief summary of some main studies of this field. The third part describes the methodology used. The fourth part reviews study limitations. The results are analyzed on the fifth and sixth part, concluded with main findings.

\section{Tax System of Kosovo}

Kosovo has relatively simple tax system and is oriented towards simple regulation that aims a broaden basis and prevention of tax evasion.

Fiscal policy, especially, tax policy is an extraordinary important part of governance of Kosovo and its economic growth, since the monetary policy tools cannot be used because euro is accepted as currency of the country. To undertake large investments and to offer vital public services, Kosovo needs a considerable quantity of resources, which could be achieved through a suitable fiscal policy. Therefore, Kosovo tax system is inseparable part of economy, because it can increase the revenues for government expenses.

\section{Transparency of Taxpayers' Rights and Obligations}

This study is focused on taxpayers, individuals and business perceptions in Kosovo with regard of TAK staff, procedures and services, and related tax policies, such as TAK access on businesses, which act against rules, audit case selection based on risk, etc. Main objective is to provide a reliable overview that presents the situation in Kosovo, related to taxpayers' opinions that can be used as basis for evaluation of new potential strategies for TAK in the future and to bring out the areas requiring priorities according to taxpayers' perception.

The design of study combines focus groups and interviews (1252) to understand the current taxpayers' opinions in Kosovo. The questions are organized on five main areas, which are:

- Transparency of Taxpayers' Rights and Obligations

Quantity results are discussed in detail through the half-structured interviews held with representatives of key institutions, and focus groups of businesses. The aim of discussions was to collect further explanations for interesting findings, and support for astounding findings.

Most of taxpayers are satisfied with approach, simplicity and clearness on provision of information by TAK. However, there is still considerable room for improvement on awareness and information about the TAK mandate on taxpayers' rights and obligations. For example, "set tax rates" and "collection of Customs duties" are seen as an important part of TAK mandate by majority of respondents. The most frequented sources for taxpayers were webpage, TAK offices or its staff and accountants. There is heterogeneity on the results with regards of age group, gender and ethnicity. New generations prefer online sources against other information means. Female taxpayers are visiting more frequently the TAK offices than male taxpayers. The members of Serbian community are using the offices or accountants as information sources and they never refer to internet webpage, based on results of the study. There were improvements in relation to speed and effective transmission of information by TAK, based on conclusions extracted from the discussion. However, there is room to move further on this direction, especially with regard of explanation on last legal changes.

On of the main boosters for this study was the idea to get a clear overview on taxpayer perception, awareness and knowledge for TAK and its services. Being informed and educated on these matters improves the chances of action in compliance with tax laws. When the tax liabilities 
are in question, this way of thinking raises furthermore the education on sanctions. With other words, it is essential that taxpayers are informed and educated before they are penalized for noncompliance. During questioning of respondents on their knowledge about TAK, a certain wrong options were set intentionally on survey to test their knowledge with regard of TAK mandate. Taxpayers' knowledge on TAK mandate sometimes is confused on certain areas, which have nothing to do with this institution. For example, on Figure 3 below, shows that "imposing of tax rates" is mentioned by $63 \%$ of respondents as important part of TAK mandate. It seems that there is confusion among the population on duties and responsibilities of each institution with regard of taxes. The clearness on relevant institution where they address and keep responsible for, are the key of a functional tax system.

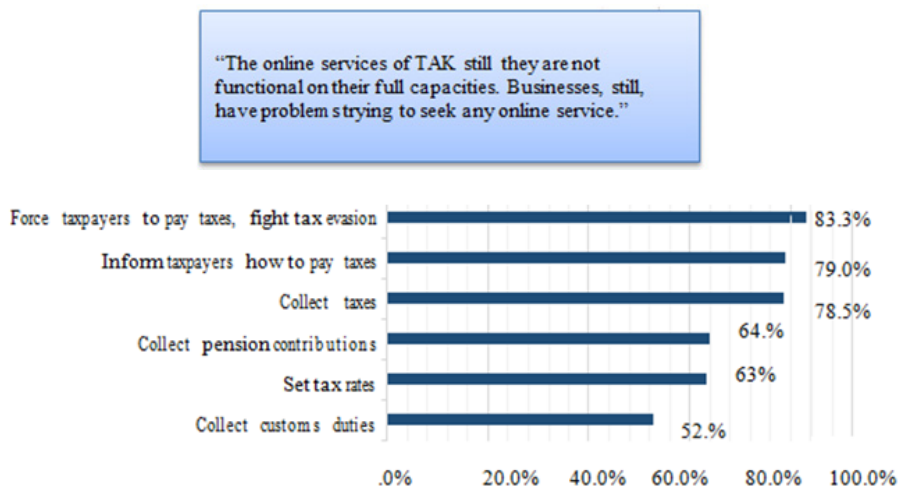

Figure 1: Perceptions on important parts of TAK mandate

Identification of main channels of information that are used by individual taxpayers and businesses would enable TAK to reach larger and diverse audience. The results from quantitative study show that the most used are TAK offices and staff, or its internet webpage. The alternative ways to reach the contact, as leaflet, social networks and call centers are rarely used as information points on related tax matters. The Figure 4 bellow summarizes the different points of information.
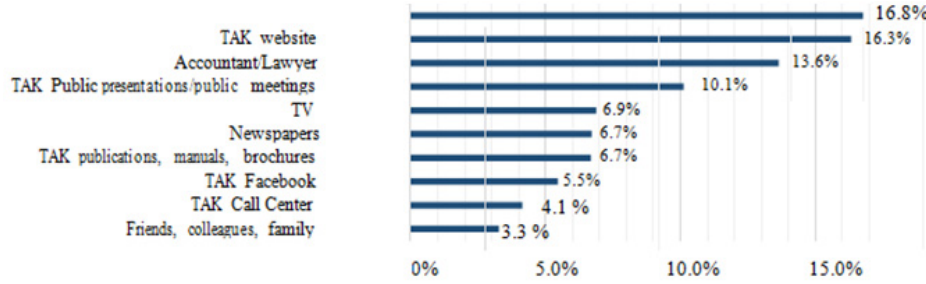

$20.0 \%$

Figure 2: Information Resources

The results of the study are further based on discussions of focus group. Most of respondents are using the internet webpage to obtain information or they directly go to TAK offices.

TAK Strategy 2010-2015 emphasizes that call centers and other online sources are new means to secure reliable, fast and credible information. However, call centers remains less used platforms for such purposes. Luck of trust on call centers is brought up as a reason where the respondents often have identified other issues on call center, such as, the staff is not responding to phone calls or is not sufficient capable to give accurate answers. Regardless that we are living in the time of digitalization, it remains a gap between the old-age generation and new generation when the daily use of new technologies is in question. Figure 5 below shows exactly this digital gap 
with regard of sources of information. It can be seen that on old age group, the existing online sources, such as TAK webpage enjoy little popularity, and TAK offices are ranked as higher level as sources of information.

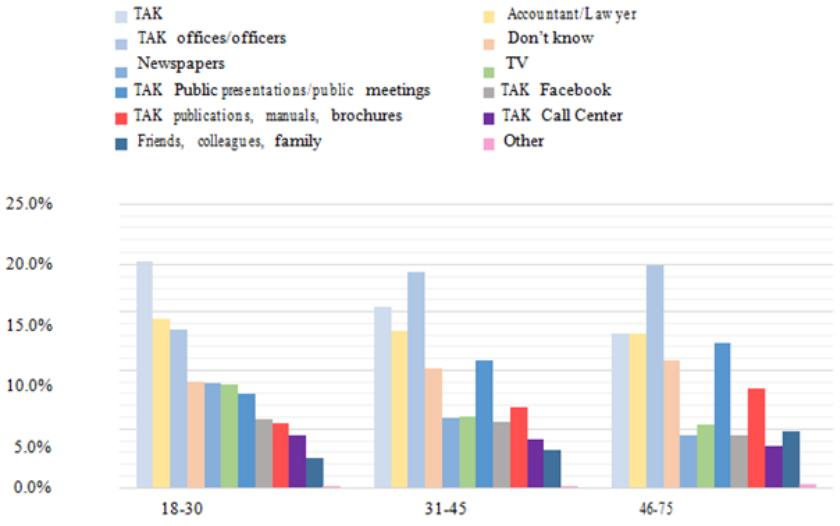

Figure 5: Sources of information - Digital division

The selection of information platforms variates among the different regions. For example, on figure 6 below it can be seen that taxpayers and businesses in Prishtina and Ferizaj follow common trends: the first choice of taxpayers is TAK webpage, followed by their personal accountant or lowyers. The region such as Prizren, Gjakova and Gjilan, the individual taxpayers and businesses are relying more on TAK offices than on webpage. Peja looks isolated, since the webpage is relatively liked, and presentations and publication, manuals and booklets are the most common sources of information.

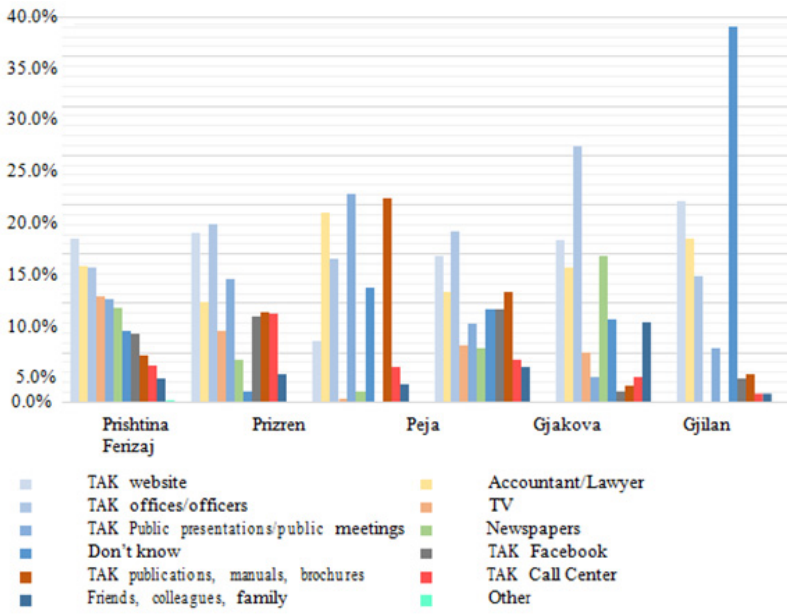

Figure 6: Sources of information by regions

The selection of platform is also dependent on taxpayers' features on seeking information. For example, on focus group held with females in business, the participants have identified themselves more as persons to avoid the risk than males. Therefore, they state that they prefer to hire capable accountants or visit TAK offices to obtain accurate and detailed information, and to avoid mistakes 
related to their tax liabilities. The results from our quantitative study shows that newspapers, TVs and accountants or lawyers are relatively popular source of information for female than male (see the Figure 7 below). However, webpage and TAK official remain more frequented for both genders.

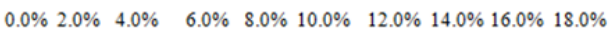

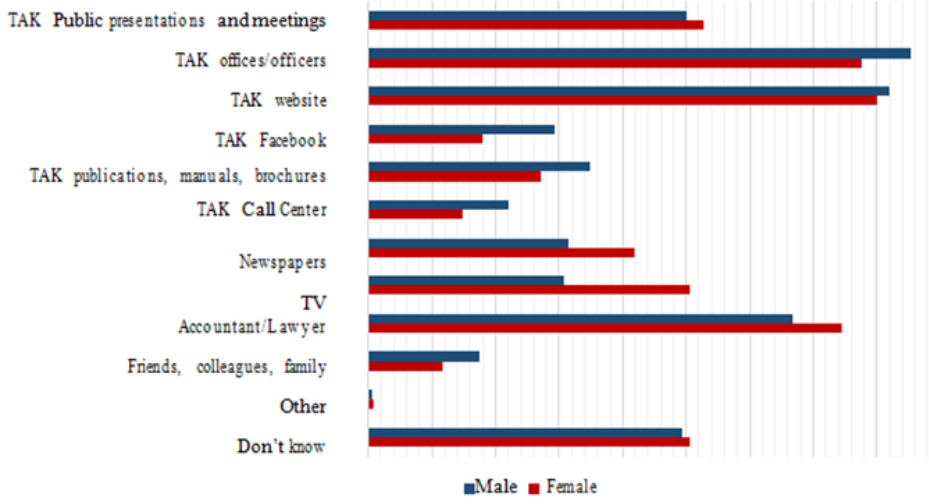

Figure 7: Sources of information by gender

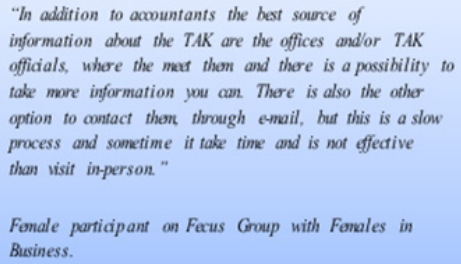

After the review of information resources for taxpayers, it is important to take their opinions on information provided by TAK. Figure 8 bellow shows the overview of surveyed taxpayers about the quality and the access on TAK information. Taxpayers are less happy with regard of information availability on rights and obligations, where $26 \%$ of taxpayers do not agree with availability on satisfaction of such information. Most of them are happy with clarity and reliability of general information. From those who sought information directly from TAK, most of them received satisfactory answers, so about $70 \%$ are inclined on positive side.

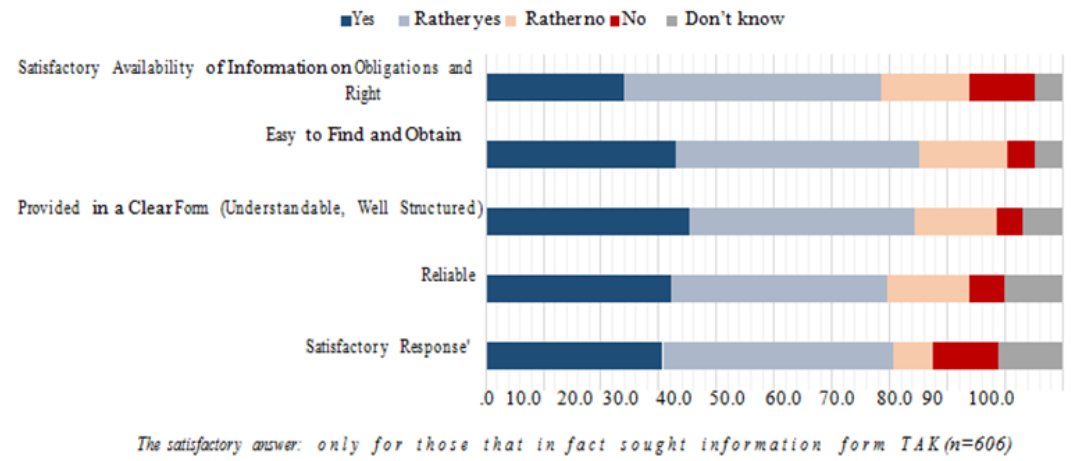

Figure 8: Opinions on information provided by TAK 
The high level of satisfaction is confirmed in some discussions on focus group. As long as there is still a room for improvement, many people believe that quality, access and availability is better than before. In the focus group of stakeholders, one of the participants said that now TAK officials can provide timely interpretation of laws and regulations. However, there are elements that require more attention. For example, officials and representatives of different institutions and business associations have shown concern, during the interview, with regard of lack of frequent updates of information materials provided on internet. Moreover, other key stakeholders were occupied with friendly approach towards the opposite gender by the TAK official. Another group of stakeholders expressed the concern about the content and details of the already provided information.

The issues that were mentioned often were connected to lack of clear and comprehensive information on recent tax law changes. However, this issue is beyond the scope of this report. In addition, the high level of satisfaction does not coincide with opinions of businesses working in Serbian community. First, main information resources for them are the accountants and lawyers, and the findings from quantitative interviews were confirmed on the focus group held with them.

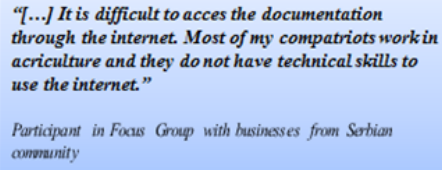

Last, the access and level of information can be explained by two points of views. In one side, the availability of information, this can be seen as duty and responsibility of TAK. From the findings of this study synthesized above, we can conclude that there are improvements on this aspect. However, more effort should be made to different focused groups, as for example a more friendly gender approach and more efforts on establishment of contact with Serbian community members. Also, special attention should be dedicated to new legal changes for micro and small enterprises, since it happens that they do not employ accountants and it is difficult for them to accept new changes.

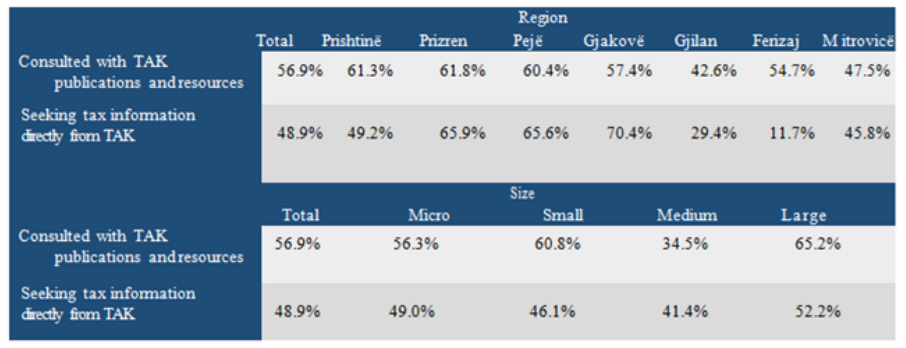

On the other side, it's the level of interest expressed by taxpayers to obtain information. With the focus group of man in business, the participants stated that interest of taxpayers is low and most of them take the initiative only when they are in trouble.

The discussion in focus group with main stakeholders of the area has discovered regional, sector and size differences on the level of taxpayers' education and knowledge. According to participants the businesses operating in Prishtina are more proactive in contact with TAK or to stay updated with tax changes. The results of quantitative interviews shown on the table 5 below present the percentage of taxpayers or individual businesses that were trying to contacts TAK and it sorts them by region and size (for businesses). About $57 \%$ of respondents have actively sought information on TAK publications and sources, and $49 \%$ of respondents have sought information directly from TAK on related to tax matters. 


\section{Conclusions}

This study has collected and analyzed the findings from a number of data collection activities, respectively quantitative studies, half-structured interviews and focus groups. Its main goal is to inform the public and TAK with regard of opinions and perceptions of taxpayers about TAK and its services. In addition, this study aims to discover the pattern of quantitative and qualitative data on TAK's transparency and professionalism. Findings will serve for improvement of future strategies, and in general on determination of current standing of Kosovo taxpayers.

Results from this study show that the level of awareness and information of TAK mandate and taxpayers' rights and obligations is in average low, since for example "set tax rates" and "collection of Customs duties" were seen as TAK mandate by most of respondents. However, the range of access, simplicity and clearness on provision of information by TAK are acceptable by interviewed taxpayers. Most frequented sources by taxpayers were the webpage, TAK offices or personnel and its accountants. However, there were differences on the popularity on sources of information among age-groups, genders and ethnicity. The discussions have found that even the speed and effective transmission of information from TAK is improved substantially recent years, more effort should be made in addressing the confusions among the taxpayers. In particular, it is emphasized the lack of clear and comprehensive information on recent changes of tax laws.

The burden of compliance is reduced considerably recent years, especially when in use are put new electronic mechanisms and simplicity of procedures. According to taxpayers it remains a problem with refunds and submission procedures of appeals. With regard of these last two, they are not the only problem including the time spent, but also the approach that TAK inspectors are using sometime.

In general the level of satisfaction is quite high on quantitative interviews with regard of respondents' satisfaction in relation to professionalism and fair treatment by TAK officials and staff. In addition to, the discussions have discovered some further concerns with regard of lack of technical qualification of TAK staff, especially those who are in direct contact with businesses. A considerable part of taxpayers agreed that bribe and misuse are not rare for TAK inspectors, even so a considerable part of them chose "I do not now" on the questions with regard of misuse of authority by TAK officials or their willingness to take bribe.

Last, the study discovered which are the main motivations for tax compliance or noncompliance by taxpayers in Kosovo. The main driver for tax compliance is seen as the fulfillment of civic duty for Kosovo. However, their main concern is the perception of misuse of public funds by the Government, which they think that very often it may drive taxpayers to non-compliance of tax obligations. Other important factors of non-compliance are the perception of tax evasion by rich people and failure of payment of taxes by competitors.

\section{References}

Alm J. dhe të tjerët (1992). "Pasiguria institucionale dhe pajtueshmëria e tatimpaguesve." Shqyrtimi Ekonomik Amerikan. Vëllimi 82, Edicioni 4, faqe 1018-1026

Devos, K. (2014), Faktorët që ndikojnë në sjelljen individuale të pajtueshmërisë tatimore, Botuesi Springer, ISBN: 978-94-007-7475-9

Hichem K., Imen Achek, (2015). "Përcaktuesit e evazionit tatimor: shqyrtimi i literaturës", Zhurnali Ndërkombëtar i Ligjit dhe Menaxhimit, Vëllimi 57, Edicioni 5, faqe 486 - 497

Ministria e Financave, Kosovë (2015). Programi Kombëtar i Reformës Ekonomike (NERP). marrë nga: https://mf.rks-gov.net/Portals/0/Programi\%20Komb\%C3\%ABtar\%20p\%C3\%ABr\%20Reforma\%20n\%C3\% AB\%20Ekonomi/2015\%20National\%20Economic\%20Reform\%20Programme.pdf

Riahi-Belkaoui, A. (2004), "Raporti ndërmjet pajtueshmërisë tatimore në aspektin ndërkombëtar dhe përcaktuesit e përzgjedhur të moralit tatimor", Zhurnali i Kontabilitetit, Auditimit dhe Tatimimit Ndërkombëtar, Vëllimi 13, nr. 3, faqe 135-143.

Richardson, G. (2006). "Përcaktuesit e evazionit tatimor: Hetimi në mbarë vendin". Zhurnali i Kontabilitetit, Auditimit dhe Tatimimit Ndërkombëtar, Vëllimi 15, Edicioni 2, faqe 150-169.

Saad N. (2014), Njohuritë tatimore, kompleksiteti tatimor dhe pajtueshmëria tatimore: Pikëpamjet e tatimpaguesve". Procedia: Shkencat sociale dhe bihevioriste (të sjelljes). Vëllimi109, faqe 1069-1075 
Administrata Tatimore e Kosovës (2011). Strategjia e Pajtueshmërisë 2012-2015. Marrë nga: http://www.atkks.org/wp-content/uploads/2011/11/COMPLIANCE_STRATEGY_2012-2015.pdf

Administrata Tatimore e Kosovës (2010). Plani Strategjik 2010 - 2015. Marrë nga: http://www.atk-ks.org/wpcontent/uploads/2010/10/Plani_Strategjik_materiali_Fundit_ENG.pdf

Banka Botërore (2014), Të hyrat e sektorit publik të Republikës së Kosovës: Politikat tatimore, evazioni tatimor dhe mangësitë tatimore. Raporti nr.: 89195 XK

Zeka E. dhe të tjerët (2013). Të paguaj apo të mos paguaj: Këndvështrimi i biznesit të informalitetit në Kosovë. Instituti për Hulumtime Zhvillimore (RIINVEST). Marrë nga: http://www.fesprishtina.org/wb/media/Publications/2013/BUSINESS_INFORMALITY_ENG_FINAL.p 